\title{
An econometric model on bilateral trade in education
}

\section{using an augmented gravity model}

\author{
Christina Tay \\ Chinese Culture University (Taiwan) \\ christwmy1203@gmail.com
}

\section{Abstract:}

Purpose: Trade in education has become one of the most important trades for many economies. Yet, studies of education as a trade are scant owing to the conventional view of it being non-tradable. The purpose of this paper is to econometrically investigate trade in education using a nexus of international trade theories and the gravity model, one of the most widely used models in international trade in goods that has been scantly investigated on in studies on trade in education.

Design/methodology/approach: A panel data analysis is broken down for 21 exporting countries and 50 importing countries, covering 1050 observations using new UNESCO database. A number of determinants of international trade including wealth of exporter \& importer, domestic capacity of exporter \& importer, transport costs, common religion, common language and trade restrictiveness of the importer are empirically tested on bilateral trade flows in education. An econometric model is formulated to test determinants of trade in education using an augmented gravity model.

Findings: The augmented gravity model used in this study explains with high significance the determinants of trade in education including wealth of exporter \& importer, domestic capacity of exporter \& importer, transport costs, common religion, common language and trade restrictiveness of the importer. 
Research limitations/implications: Taking a macroscopic view of education as a trade may give us a myopic view of the elements important to determine what students or parents of students as well as institutions are concerned with. Nevertheless, the nexus of international trade theories and the gravity model used in this study that are largely and traditionally used on trade in goods and services, but scantly used in trade in education have been found to be highly significant and relevant in trade in education. Future studies on macro-level of analysis involving trade in education could include other determinants of trade in education or trade in goods/services to test for their relevance and significance in this area of study.

Practical implications: This paper aims to contribute to existing literature on trade in services and trade in education by borrowing some of the same assumptions on market structures usually made for services and international trade to show that the international trade theories can help explain the pattern of trade in education. The econometric model formulated enables governments to design policies that could facilitate, direct and promote the development and growth of education as a trade. It could also assist institutions to adjust and choose more efficient methods of structuring their policies and formulating their marketing strategies, targeted towards different country segments.

Social implications: With the share of education services in world trade increasing, it becomes even more important to be able to accurately model trade in education services. Thus, my introduction of the augmented gravity model on trade in education provides new and interesting avenues for further macro research of trade in education on an international platform.

Originality/value: I borrow the same assumptions on market structures usually made for services to show that international trade theories can help explain the pattern of trade in education. This paper proposes an effective econometric model using the gravity equation to help governments as well as institutions evaluate the importance of the various determinants of trade in education.

Keywords: trade in services, international trade, trade in education, gravity model, trade restrictiveness, Generally Accepted Trade in Services(GATS), consumption abroad

\section{Introduction}

The importance of services industry seems to be acknowledged well. Nevertheless, compared to manufacturing, the service sector has received less attention and considered as relatively 
immature (Suhaiza, Mohd \& Kavigtha, 2011). Trade in education has become one of the single largest services sector in terms of shares in Gross Domestic Product(GDP)and employment for many economies. Trade in education also provides the bulk of employment and income in many countries and serves as a vital input for producing other goods and services. For developed nations like New Zealand, Australia, the United Kingdom, the United States and Canada, education exports contribute up to $1.13 \%, 1.06 \%, 0.4 \%, 0.5 \%, 0.25 \%$ of their GDPs, respectively (Crawford, 2009;Boag, 2011; Douglass, Edelstein \& Hoaraeu, 2011).

However, there is a lack of study on education as a trade owing the conventional view of it being non-tradable and an intangible service. Much research has been conducted on international trade in services than on trade in education despite the latter's strong importance in many economies and the burgeoning importance of trade in services. There is a handful literature that investigates using the gravity model on education, in general or at a unit-level of analysis, but not on trade in education at a macro level. Most are predominantly confined to choice of an education institution, regional demand, choice of university site, or relationship between education and multinational affiliates, and do not address determinants of international trade in education exports at a worldwide-level of analysis (Leppel, 1993;Sá, Florax \& Rietveld, 2003; Sá, Florax \& Rietveld, 2004, 2006; Shatz, 2003; Giuseppe \& Gennaro, 2008).

The purpose of this paper is to econometrically investigate trade in education using the gravity model, one of the most widely used models in international trade in goods that has been scantly investigated on in studies on trade in education. Thus, I aim to contribute to existing literature on trade in services and trade in education in several ways. First, I borrow the same assumptions on market structures usually made for services to show that international trade theories can help explain the pattern of trade in education. As far as I know, there have been no direct attempts to use the gravity framework to estimate bilateral trade in education at a worldwide level of analysis. Second, the nexus of international trade theories and the gravity model on trade in education is explored for the first time. Third, the relevance of traditional measures of bilateral trade such as population, GDP, distance, common borders \& language and trade restrictiveness are tested. This paper proceeds as follows: Section 2 reviews literature on the gravity model; section 3 presents my econometric model, discusses data \&measurement issues, section 4 presents the results, and finally, section 5 concludes.

\section{Literature Review}

The traditional gravity model drew an analogy with Newton's law of Gravitation. $X_{i j}$ is the predicted movement of goods or labor between I and $\mathrm{j}$. A mass of goods or labor or other factors of production supplied at origin $i, Y_{i}$ is attracted to a mass of demand for goods or labor at destination $j, E_{j}$ and inversely related to the square of their distance between them, $D_{i j}$. 


$$
\mathrm{Tij}=\mathrm{YiEj} / \mathrm{D}^{2} \mathrm{ij}
$$

Originally applied to international trade, Tinbergen (1962) was the first to apply the standard gravity equation to predict bilateral trade flows between any two countries as a function of their size and distance between them. Economic size is measured as Gross Domestic Product, and distance is typically measured as the distance between countries' capital cities. The gravity model has also been widely applied in international trade studies and successfully applied to flows of varying types such as migration, foreign direct investment, and more specifically to international trade flows (Zarzoso \& Felicitas, 2003). The model specification has also been augmented through the addition of other variables that are thought to impact on trade flows including common language and common religion.

A handful of existing literature applies the gravity model to education. Leppel (1993) is the first to attempt to estimate the gravity model using logit analysis on college enrollment decision. The data employed in this study are based on a set of students who had been accepted at a particular university to determine the factors influencing a student's decision to enroll at that school. A gravity model using logit analysis is performed to determine what factors influence a student's final decision to enroll or not to enroll at that institution.

In an extension of this approach, Sá et al. (2004) investigates the determinants of university entrance for Dutch high school graduates. The gravity model is modified paying particular attention to the attractiveness of the university, both in terms of its accessibility and the educational quality of its programs. The main finding is that the behavior of prospective students is governed by a distance deterrent effect and a downward rent effect, but a positive impact results from regional/urban amenities rather than from the educational quality of the university programs. Sá et al. (2004) apply the gravity model to investigate determinants of regional demand for higher education in the Netherlands emphasizing the relevance of socioeconomic factors, but leave spatial dimensions of the prospective students' university choices largely unexplored.

Sá et al. (2006) then extended the gravity model to identify pivotal factors behind individual decision making in the transition from high school to post-secondary education in the Netherlands and apply a multinomial logit framework to individual data to analyze the impact of geographical accessibility of the higher education system and allow the individual observations to be correlated within schools, in effect accounting for localized social interactions. The main findings show that geographical proximity significantly increases the probability of high school leavers continuing their education at a university or professional college.

Shatz (2004) investigates the relationship between education and the location of U.S. multinational affiliates using a gravity equation framework. Using a gravity equation framework, the analysis introduces a methodological innovation by including numerous 
economies that receive no investment. The expanded data set reveals that about two-thirds of the variation in multinational location can be explained by the standard gravity variables of host country size, transport costs, distance from the investing country, and host country remoteness. Giuseppe and Gennaro (2008) adapted Newton's law of gravitation to an economic case using the gravity model to describe the behavior of potential students in the choice of a university site and comparing the results with the actual data. The results provided by the model have been compared with the actual data and show that the gravity model can describe the behavior of potential students with good approximation.

A review of existing literature shows that most studies apply the gravity to education, in general or at a unit-level of analysis, including choice of an education institution, regional demand, choice of university site, or relationship between education and multinational affiliates (Leppel, 1993; Sá et al., 2003; Sá et al., 2004, 2006; Shatz, 2003; Giuseppe \& Gennaro, 2008). To my knowledge, no existing study has attempted to apply the gravity education to trade in education, and at a worldwide-level of analysis.

\section{The Econometric Specification}

One may claim that a different gravity equation framework is needed for trade in education recognizing that there may be some characteristics that distinguish between trade in education and trade in goods or services. I find no reason to provide a separate equation for trade in services with that in trade in education, which theoretically, is also a form of trade in services. The gravity equation should, in theory, be as appealing for trade in education since many factors including both trade impediments(distance, trade restrictions) and preference factors(common religion, common language, land border, English language, etc. ) carry very similar service characteristics.

Hence, the standard gravity equation is augmented to include determinants that are posited to impact and able to project bilateral trade in education. In order to estimate the equation, a dependent variable, $\ln \mathrm{Y}_{\text {eit, }}$ in $\log$ form, is used to represent the trade in education from an exporting country, e to an importing country, $i$. Thus, the augmented gravity equation takes the following form:

$\ln Y_{\text {eit }}=\alpha+\beta 1 \ln G_{e t}+\beta 2 \ln G_{i t}+\beta 3 \ln P_{e t}+\beta 4 \ln P_{i t}-\beta 5 \ln D_{e i}+\beta 6 R_{e i}+\beta 7 L_{e i}+\beta 8 \ln F_{e}-\beta 9 \ln F_{i}+\gamma_{e}+\gamma_{i}+\gamma_{t}+U_{\text {eit }}$

The three-dimension panel structure of the data implies the export country $\left(\mathrm{Ye}_{\mathrm{e}}\right)$, import partner $\left(\gamma_{i}\right)$ and time-specific effects $\left(\gamma_{t}\right)$ and is a random disturbance ( $\left.u_{\text {eit }}\right)$. I use international flows of mobile students at the tertiary level as a proxy for bilateral trade in education. This data is obtained from the United Nations Educational, Scientific and Cultural Organization (UNESCO). My estimations concern 21 exporters and 50 importers for the year 2010 covering 
a total of 1050 observations. The list of 21 exporters and 50 importers are shown in Appendix A.

My dependent variable data identifies transactions of reporting countries as defined by Generally Accepted Trade in Services (GATS) under Mode 2. The GATS distinguishes amongst four modes of supply in services trade.

- Mode 1:Cross-border supply where services are supplied from one country to another.

- Mode 2: Consumption abroad, where consumers go to another country to consume the service.

- Mode 3: Commercial presence of the provider in another country.

- Mode 4: Presence of natural persons, where individuals travel from their own country to supply services in another.

Each mode has a varying degree of barriers related to it. Mode 2 has the least number of barriers that need to be removed, followed by Mode 1; followed by Mode 4, and finally Mode 3 . In my study, I choose Mode 2 which is the largest of all four modes of trades in education.

A relatively higher level of income in an exporting country to an importing country suggests greater wealth which in turn confers higher quality of education exports provided that is expected to increase demand for exports. Conversely, a relatively lower level of income in an importing country to an exporting country suggests lower quality in domestic education and increases demand for imports. As measurements for $\left(G_{j t}\right)$ and $\left(G_{i t}\right)$, I use GDP of an exporting/importing country in time, $t$. I expect the coefficients $\beta 1$ and $\beta 2$ to be positive.

The higher the population of an importing country relative to a partnering country indicates domestic capacity for internal demand for education exports that cannot be completely absorbed by that country, and thus, increasing the demand for imports, and vise-versa. Therefore, I expect $\beta 3$ and $\beta 4$ to be positive. As measurements for $\left(P_{\text {et }}\right)$ and $\left(P_{i t}\right)$, I use an importing/exporting country's population, in time, $t$.

Traditionally, the gravity model uses distance to model transport costs as well as other forms of impediments. The distance $\left(\mathrm{D}_{\mathrm{ei}}\right)$ between the importer and exporter is measured between the capitals of both countries and is expected to hold a negative sign. I expect the coefficient $\beta 5$ is to be negative and is taken as a proxy of all possible transport cost that may be deterrent. My two dummy variables, common language $\left(L_{e i}\right)$ and common religion $\left(R_{e i}\right)$,indicate whether either or both trading partners share common religion/language which would facilitate and act as attractive forces between trading partners. Thus, the coefficients of both of these variables $\beta 6$ and $\beta 7$ are expected to be positive. 
Finally, I include trade restrictions of the exporter $\left(F_{\text {et }}\right)$ and importer $\left(F_{i t}\right)$. The coefficient of $\left(F_{\text {et }}\right)$ is posited to be positive, whilst $\left(F_{i t}\right)$ is posited to have a pulling-back effect and expected to hold a negative sign. The Economic Freedom of the World (EFW) Index is used as a measurement for both of these variables. This data is published by the Fraser Institute of Canada and EFW measures the consistency of a nation's policies and institutions with economic freedom. EFW is a composite index which measures the degree of economic freedom present in five major areas:

- size of government,

- legal structure and security of property rights,

- access to sound money,

- freedom to trade internationally, and

- regulation of credit, labor, and business.

\section{Results and Check for Robustness}

My study includes trade flows between randomly drawn samples of trading partners from a larger population which could lead to multicollinearity problems. To tackle this problem, I use a two-pronged approach. First, I estimate the results of the panel regression using the ordinary least squares (OLS) method, where the types of fixed effects are constrained to equal the constant: $Y=Y_{e}+Y_{i}+Y_{t}$. Models (1) to (3) in Table 1 show the panel regression results using OLS. Two checks for multicollinearity are used: the variance inflation factor (VIF), and the Durbin-Watson. As a benchmark, if the VIF is less than or around 5, then multicollinearity was not a problem in my analysis. The VIFs of all the explanatory variables are within a safe range of less than 5, suggesting multicollinearity was not a problem in the analysis. Second, all the Durbin-Watson results in Table 1 are less than 1.8 , indicating there is no first-order autocorrelation. As a rule of thumb, an acceptable Durbin-Watson range lies in between 1.50 and 2.50 , and a value of 2 or nearly 2 indicates that there is no first-order autocorrelation.

Second, I estimate the regression using a fixed effects model(FEM) and results are shown in Table 2 of Models (4) to (6). The explicit introduction of FEM could generate multicollinearity as some of the variables used vary across exporters or importers since the intercept terms are allowed to vary over the individual units (in this case the importing and exporting country pairs), but are held constant over time. Again the two tests for multicollinearity are used. All the VIF for the explanatory variables are less than 5, showing no signs of multicollinearity. The Durbin-Watson values are all less than 1.8 for Models (4) to (6), again showing no signs for my second check of multicollinearity. 
Table 1 shows the estimation results of the panel regression results using the ordinary least squares (OLS) method. In Model 1, I estimate a traditional gravity relationship for bilateral trade in education using wealth of exporter/importer, domestic capacity of exporter/importer and distance determinants. All the variables have the expected signs and all the coefficients are highly significant at $0.01 \%$ except for transportation costs, which appears to be insignificant. This result rebukes traditional gravity models that distance is a major impediment to trade. One explanation for this may be that exporters possess relatively more advanced infrastructure including transportation \& communication systems which reduces such costs for importers, making this determinant not as important as shown in existing studies of traditional theories of trade.

When common language \& religion are introduced in Model 2, wealth of exporter, domestic capacity of exporter/importer, common religion and language are highly significant at $0.01 \%$. Wealth of the importer is significant at $5 \%$. Transport cost is significant at $10 \%$ although this time, the wealth of the importer drops in significance from $1 \%$ to $5 \%$. When I introduce trade restrictiveness of the exporter \& importer in Model 3; domestic capacity of exporter/importer, wealth of exporter, common language and common religion all have the expected signs' and are highly significant at $0.01 \%$. The wealth of the importer is less significant than that of the exporter, holding a value of $1 \%$. Transportation cost has the correct sign, but is insignificant. Trade restrictiveness of the exporter is insignificant here. On the other hand, trade restrictiveness of the importer is significant at $10 \%$ and holds the expected negative sign. This shows that if a country has a relatively high average trade barrier, it will trade more with a country with which it has a low bilateral barrier.

Models (4) to (6) in Table 2 shows the panel regression results using the fixed effects model (FEM). In Model 4, I estimate a traditional gravity relationship for bilateral education exports including wealth of exporter/importer and domestic capacity of exporter/importer. All these variables have the expected signs and their coefficients are highly significant at $0.01 \%$. The wealth of the importer is significant at $1 \%$ but, lower than that of the exporter's showing for one, wealth is a major factor for importers, and two, exporters possess a relatively stronger economic position providing advantages to their domestic markets. When I introduce common language \& religion in Model 5, wealth of exporter, domestic capacity of exporter/importer, common religion \& language have the expected signs and are highly significant at $0.01 \%$. The wealth of the importer is significant at $1 \%$. When trade restrictiveness of the exporter\& importer are introduced in Model 6, domestic capacity of exporter/importer, wealth of exporter, common language $\&$ religion have the expected signs and are highly significant at $0.01 \%$. The significance of wealth of importer is at $1 \%$, lower than that of the wealth of the exporter. Trade restrictiveness of the exporter is not significant here. Conversely, the trade restrictiveness of the importer plays a more significant role, holding a negative sign and is significant at $5 \%$. One explanation for this is that the exporters are relatively more open market than the majority of its partnering countries, and liberalizes most of its services market. 


\section{Conclusion}

This paper has argued that the gravity model can be applied to international trade in education, where my analysis is the first to exploit the international trade dimension to elucidate the determinants of education services trade flows. This paper finds that traditional measures of bilateral trade such as population, Gross Domestic Product, common borders, common language and trade restrictiveness of the importer are highly significant to trade in education. My augmented gravity model is also able to explain most of the determinants of trade in education, with the exceptions of trade restrictions of the exporter and distance. When ranked in order of importance, trade restrictiveness of the importer, wealth of the exporters and importers, common religion \& language, domestic capacity of the exporter/importer are very significant, whilst distance and trade restrictiveness of the exporter are insignificant. The results in my study have some wider implications. With the share of education services in world trade increasing, it becomes even more important to be able to accurately model trade in education. Another interesting result I find concerns the impact of the trade restrictions of trade in education. Liberalization in trade in education is still slow to develop and thus, governments and education institutions could work more closely to liberalize this trade in order to realize its greater economic contributions to economies and institutions worldwide.

\section{References}

Boag, S. (2011). New Zealand 'punching above its weight' in Export Education, Education New Zealand: Media Release. Retrieved November 26th, 2011, from: http://www.educationnz.org.nz/comm/Mediarealeases/Punching\%20Above\%20Weight-26-11-08.pdf

Crawford, R. (2009). Universities Key to Building Export Education Industry, Te Pokai Tara. Retrieved February 20th, 2009, from: http://www.universitiesnz.ac.nz/node/364

Douglass, J.A., Edelstein, R., \& Hoaraeu, C. (2011). US Higher Education as an Export: It is about the money, but also much more, Center of studies in higher education. Retrieved April 28th, 2011 from: http://cshe.berkeley.edu/news/index.php?id=89

Fraser Institute (2010). Economic freedom of the world index. Retrieved October 15th, 2013 from: http://www.freetheworld.com/release.html

Generally Accepted Trade in Services (GATS). Retrieved October 15th, 2013 from: http://www.wto.org/english/tratop e/serv e/gatsintr e.htm

Giuseppe, B., \& Gennaro, I. (2008). Using gravity models for the evaluation of new university site. Computers \& Operations Research, 35, 436-444. http://dx.doi.org/10.1016/j.cor.2006.03.008 
Leppel, K. (1993). Logit estimation of a gravity model of the college enrollment decision. Journal of Research in Higher Education, 34(3), 387-398. http://dx.doi.org/10.1007/BF00991851

Sá, C., Florax, R.J.G.M. \& Rietveld, P. (2004). Determinants of the Regional Demand for Higher Education in The Netherlands: A Gravity Model Approach. Regional Studies, 38(4), 375-392. http://dx.doi.org/10.1080/03434002000213905

Sá, C., Florax, R.J.G.M. \& Rietveld, P. (2006). Does Accessibility to Higher Education Matter? Choice Behaviour of High School Graduates in the Netherlands. Spatial Economic Analysis, 1(2), 155-174. http://dx.doi.org/10.1080/17421770601009791

Shatz, H. (2003). Gravity, education, and economic development in a multinational affiliate location. The Journal of International Trade \& Economic Development: An International and Comparative Review, 12(2), 117-150. http://dx.doi.org/10.1080/0963819032000084368

Suhaiza, H., Mohd, Z., \& Kavigtha, M.K. (2011). Service supply chain (SSC): proposed SSC practices measurement items for empirical testing. ISSN 1816-6075 (Print), 1818-0523 (Online) Journal of System and Management Sciences, 1(5), 13-23.

Tinbergen, J. (1962). Shaping the World Economy: Suggestions for an International Economic Policy. New York: The Twentieth Century Fund.

UNESCO (United Nations Educational, Scientific and Cultural Organization Institute of Statistics) (2010). Retrieved October 15th, 2013 from: http://stats.uis.unesco.org

Zarzoso, M.I., \& Felicitas, N.L. (2003). Augmented Gravity Model: An empirical application to Mercosur-European Union Trade Flows. Journal of Applied Economics, 6(2), 291-316. 


\section{Appendix A: List of Importing and Exporting Countries}

\section{- List of Importing Countries}

Argentina, Australia, Austria, Belgium, Brazil, Canada, Chile, China, Colombia, Czech Republic, Denmark, Egypt, Estonia, Finland, France, Germany, Greece, Hong Kong, Hungary, Iceland, India, Indonesia, Ireland, Israel, Italy, Japan, Kenya, Malaysia, Mexico, Nepal, Netherlands, New Zealand, Nigeria, Norway, Pakistan, Poland, Portugal, Russian Federation, Serbia, Singapore, Slovenia, South Africa, South Korea, Spain, Sweden, Switzerland, Thailand, Turkey, United Kingdom, United States of America.

\section{- List of Exporting Countries}

Australia, Austria, Belgium, Canada, Denmark, Finland, France, Germany, Ireland, Italy, Japan, Netherlands, New Zealand, Norway, South Korea, Spain, Sweden, Switzerland, Turkey, United Kingdom, United States.

\begin{tabular}{|c|c|c|c|}
\hline \multirow{2}{*}{$\begin{array}{l}\text { Dependent Variable } \\
\text { Model }\end{array}$} & \multicolumn{3}{|c|}{ Bilateral Trade in Education } \\
\hline & $\mathbf{1}$ & 2 & 3 \\
\hline Explanatory Variables & & & \\
\hline Wealth of exporter & $1.732(0.000) * * * *$ & $1.501(0.000) * * * *$ & $1.495(0.000) * * * *$ \\
\hline Wealth of Importer & $0.214(0.001)^{* * *}$ & $0.15(0.015)^{* *}$ & $0.250 .003 * * *$ \\
\hline Domestic capacity of exporter & $0.711(0.000) * * * *$ & $0.727(0.000) * * * *$ & $0.726(0.000) * * * *$ \\
\hline Domestic capacity of importer & $0.57(0.000)^{* * * *}$ & $0.624(0.000) * * * *$ & $0.606(0.000) * * * *$ \\
\hline Distance & $-0.041(0.37)$ & $-0.076(0.094)^{*}$ & $-0.069(0.138)$ \\
\hline Common religion & & $0.916(0.000)^{* * * *}$ & $0.877(0.000)^{* * * *}$ \\
\hline Common language & & $0.883(0.000) * * * *$ & $0.919 *(0.000) * * *$ \\
\hline Trade restrictiveness of exporter & & & $0.14(0.929)$ \\
\hline Trade restrictiveness of importer & & & $-1.819(0.077)^{*}$ \\
\hline Constant & $-37.104(0.000) * * * *$ & $-35.731(0.000) * * * *$ & $-33.062(0.000) * * * *$ \\
\hline Observations & 1046 & 1044 & 1044 \\
\hline R-squared & 0.241 & 0.284 & 0.286 \\
\hline Durbin-Watson & 1.772 & 1.746 & 1.753 \\
\hline F-test & 66.217 & 58.632 & 46.006 \\
\hline VIF values & $\begin{array}{l}\text { (a) } 1.22 ; \\
\text { (b) } 1.372 ; \\
\text { (c) } 1.223 ; \\
\text { (d) } 1.333 ; \\
\text { (e) } 1.082\end{array}$ & $\begin{array}{l}\text { (a) } 1.257 ; \\
\text { (b) } 1.439 ; \\
\text { (c) } 1.232 ; \\
\text { (d) } 1.368 ; \\
\text { (e) } 1.093 ; \\
\text { (f) } 1.166 ; \\
\text { (g) } 1.024\end{array}$ & $\begin{array}{l}\text { (a) } 1.527 ; \\
\text { (b) } 2.651 ; \\
\text { (c) } 1.347 ; \\
\text { (d) } 1.435 ; \\
\text { (e) } 1.158 ; \\
\text { (f) } 1.191 ; \\
\text { (g) } 1.106 ; \\
\text { (h) } 1.661 ; \\
\text { (i) } 2.4\end{array}$ \\
\hline
\end{tabular}

Notes:

1. *significant at $10 \%, * *$ significant at $5 \%, * * *$ significant at $1 \%, * * * *$ significant at $0.01 \%$

2. Standard errors in brackets

3.VIF values are reported for each of the explanatory variables(a) (i)

Table 1. Panel Regression Results for Ordinary Least Squares using the Random Effects Model 


\begin{tabular}{|c|c|c|c|c|}
\hline & \multirow{2}{*}{$\begin{array}{l}\text { Dependent Variable } \\
\text { Model }\end{array}$} & \multicolumn{3}{|c|}{ Bilateral Trade in Education } \\
\hline & & 4 & 5 & 6 \\
\hline & Explanatory Variables & & & \\
\hline$a$ & Wealth of exporter & $1.726(0.000) * * * *$ & $1.51(0.000) * * * *$ & $1.529 *(0.000) * * *$ \\
\hline $\mathrm{b}$ & Wealth of Importer & $0.21(0.001) * * *$ & $0.17(0.005) * * *$ & $0.277(0.001) * * *$ \\
\hline $\mathrm{C}$ & Domestic capacity of exporter & $0.709(0.000) * * * *$ & $0.722 *(0.000) * * *$ & $0.716(0.000) * * * *$ \\
\hline $\mathrm{d}$ & Domestic capacity of importer & $0.563(0.000) * * * *$ & $0.617(0.000) * * * *$ & $0.598(0.000) * * * *$ \\
\hline $\mathrm{e}$ & Distance & & & \\
\hline $\mathrm{f}$ & Common religion & & $0.899(0.000) * * * *$ & $0.858(0.000) * * * *$ \\
\hline $\mathrm{g}$ & Common language & & $0.862(0.000)^{* * * *}$ & $0.919(0.000)^{* * * *}$ \\
\hline $\mathrm{h}$ & Trade restrictiveness of exporter & & & $-0.404(0.808)$ \\
\hline $\mathrm{i}$ & Trade restrictiveness of importer & & & $-1.981(0.053) * *$ \\
\hline & Constant & $-37.198(0.000) * * * *$ & $-36.42(0.000) * * * *$ & $-32.486(0.000) * * * *$ \\
\hline & Observations & 1050 & 1044 & 1044 \\
\hline & R-squared & 0.237 & 0.282 & 0.284 \\
\hline & Durbin-Watson & 1.769 & 1.746 & 1.75 \\
\hline & F-test & 81.08 & 67.818 & 51.422 \\
\hline & VIF values & $\begin{array}{l}\text { (a) } 1.221 ; \\
\text { (b) } 1.324 ; \\
\text { (c) } 1.221 ; \\
\text { (d) } 1.324\end{array}$ & $\begin{array}{l}\text { (a) } 1.256 ; \\
\text { (b) } 1.385 ; \\
\text { (c) } 1.228 ; \\
\text { (d) } 1.356 ; \\
\text { (f) } 1.16 ; \\
\text { (g) } 1.019\end{array}$ & $\begin{array}{l}\text { (a) } 1.505 ; \\
\text { (b) } 2.524 ; \\
\text { (c) } 1.329 ; \\
\text { (d) } 1.417 ; \\
\text { (f) } 1.183 ; \\
\text { (g) } 1.106 ; \\
\text { (h) } 1.581 ; \\
\text { (i) } 2.374\end{array}$ \\
\hline
\end{tabular}

Notes:

1. *significant at $10 \%, * *$ significant at $5 \%, * * *$ significant at $1 \%, * * * *$ significant at $0.01 \%$

2. Standard errors in brackets

3. VIF values are reported for each of the explanatory variables(a) (i)

Table 2. Panel Regression Results for Ordinary Least Squares using the Fixed Effects Model

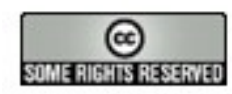

Article's contents are provided on a Attribution-Non Commercial 3.0 Creative commons license. Readers are allowed to copy, distribute and communicate article's contents, provided the author's and Journal of Industrial Engineering and Management's names are included. It must not be used for commercial purposes. To see the complete license contents, please visit http://creativecommons.org/licenses/by-nc/3.0/. 